\title{
PEMANFAATAN FUZZY LOGIC DAN HILL CLIMBING UNTUK OPTIMASI PENGELOLAAN TEMPAT PENGOLAHAN SAMPAH REDUCE-REUSE-RECYCLE (TPS 3R) PADA DINAS LINGKUNGAN HIDUP (DLH) DKI JAKARTA
}

\author{
Ramadana Arbi ${ }^{1}$, Meinarini Catur Utami ${ }^{* 2}$, Qurrotul Aini ${ }^{3}$ \\ 1,2,3 Universitas Islam Negeri Syarif Hidayatullah, Jakarta \\ Email: ${ }^{1}$ ramadana.arbi@mhs.uinjkt.ac.id, ${ }^{2}$ meinarini@ uinjkt.ac.id, ${ }^{3}$ qurrotul.aini@uinjkt.ac.id \\ *Penulis Korespondensi
}

(Naskah masuk: 10 Mei 2020, diterima untuk diterbitkan: 16 November 2021)

\begin{abstract}
Abstrak
DLH DKI Jakarta merupakan lembaga pemerintah yang bertanggung jawab terhadap pengelolaan sekitar 1.125 Tempat Penampungan Sampah Sementara (TPS) yang tersebar di lima wilayah di DKI Jakarta, yaitu Jakarta Selatan, Jakarta Timur, Jakarta Barat, Jakarta Utara dan Jakarta Pusat. Sejumlah TPS yang tersebar tersebut, turut di dalamnya beberapa TPS 3R (Reduce, Reuse, Recycle). TPS 3R lebih kompleks pemanfaatannya bila dibandingkan dengan TPS biasa karena TPS 3R selain berfungsi sebagai TPS, juga dapat untuk memperbaiki kondisi sampah atau limbah sebelum diteruskan ke TPA (Tempat Pemrosesan Akhir). Kondisi TPS 3R saat ini belum bisa maksimal fungsinya, disebabkan fasilitas yang belum memadai, seperti menurunnya kualitas alat pencacah organik, tidak adanya wadah pemilahan dan ruang pemilahan. Oleh karena itu, perlu kiranya pengucuran dana bagi TPS 3R. Akan tetapi karena terbatasnya dana, maka perlu memilih TPS 3R mana yang akan diprioritaskan mendapat bantuan dana. Oleh karena itu, penelitian ini bertujuan membangun sistem pendukung keputusan dalam menentukan prioritas TPS 3R DLH DKI Jakarta dengan menggunakan metode optimasi yang mengacu pada 5 kriteria yaitu luas lahan, fasilitas, jarak, kondisi jalan, dan kondisi estetika lingkungan, serta metode pengembangan sistem RAD (Rapid Application Development). Peneliti menggunakan metode optimasi Fuzzy Logic sebagai metode pembobotan nilai kriteria dan Hill Climbing untuk menentukan alternatif terbaik yang ada. Adapun sistem yang dihasilkan memberikan kontribusi kepada DLH yaitu dapat menentukan TPS 3R yang berhak mendapatkan bantuan dana secara cepat dan tepat.
\end{abstract}

Kata kunci: TPS 3R, fuzzy logic, hill climbing, kriteria, RAD

\section{UTILIZATION OF FUZZY LOGIC AND HILL CLIMBING FOR OPTIMIZING REDUCE-REUSE-RECYCLE WASTE MANAGEMENT (TPS 3R) AT ENVIROMENTAL SERVICES (DLH) DKI JAKARTA}

\begin{abstract}
DLH DKI Jakarta is a Government Institution that responsible for waste management about 1125 temporary waste shelters (TPS) spread across 5 Regions in DKI Jakarta; i.e South Jakarta, East Jakarta, West Jakarta, North Jakarta, and Central Jakarta. All those TPS's are including some of 3R TPS (Reduce, Reuse, and Recycle). The $3 R$ TPS is more complex in term of their usage rather than normal TPS as the 3R TPS's instead of being a normal TPS, they could also fix the rubbish or waste before send it to Final Processing Place (TPA). The 3R TPS is still functionally not maximum way to be used as inadequate facilities such as quality degradation on organic counter, and there is no mechanical separation place and its room. With that reasons, the 3R TPS needs to be financial supported. And considering the financial limitation from DKI Government, there is need to select suitable $3 R$ TPS on priorities to get financial support. Therefore, this study aims to build a decision support system in determining the priority of TPS 3R DLH DKI Jakarta by using an optimization method that refers to five criteria, namely land area, facilities, distance, road conditions, and environmental aesthetic conditions, as well as Rapid Application Development (RAD). The fuzzy logic is a method of weighting the criteria and Hill Cimbing is optimization method to determine the best of alternatives. The result contributes to DLH, which is to determine which TPS $3 R$ is entitled to receive funding quickly and precisely.
\end{abstract}

Keywords: TPS $3 R$, fuzzy logic, hill climbing, criteria, RAD 


\section{PENDAHULUAN}

Jumlah penduduk di dunia dari tahun ke tahun semakin bertambah. Pada tahun 2018, diketahui jumlah penduduk di dunia kurang lebih 7,7 milyar (Jayani, 2019). Hal ini tak terkecuali dengan di Indonesia, yang mana saat ini Indonesia menempati peringkat ke-4 negara dengan jumlah penduduk tertinggi di dunia (Rahayu, 2019). Pertumbuhan jumlah penduduk mengakibatkan adanya pergeseran nilai-nilai kehidupan, salah satunya adalah produksi sampah yang dihasilkan oleh setiap orang, terutama di kota-kota besar. DKI Jakarta sebagai ibukota negara kita, Indonesia, merupakan salah satu kota besar di Indonesia. Jumlah penghuni DKI Jakarta pun dari tahun ke tahun juga mengalami peningkatan dimana tahun 2017 berdasar info Badan Pusat Statistik sebesar kurang lebih 10 milyar. Bisa dibayangkan jumlah sampah yang diproduksi oleh penduduk sebesar itu. Untuk menampung sampah dari penduduknya, menurut info dari dokumen DLH Pemerintah Provinsi DKI Jakarta, DKI Jakarta memiliki Tempat Penampungan Sampah Sementara (TPS) pada tahun 2019 sebanyak 1.125 yang tersebar di seluruh wilayah DKI Jakarta dengan di dalamnya sudah terdapat TPS 3R sebanyak 67 unit.

Menurut Norken et al. (2019), TPS 3R merupakan tempat pengolahan sampah yang memakai prinsip Reduce (mengurangi), Reuse (menggunakan kembali), Recycle (daur ulang) untuk mengurangi volume sampah sejak dari sumbernya pada skala komunal atau kawasan. Kawasan di sini mencakup 400 rumah atau kepala keluarga. Adapun tujuan utama TPS 3R selain mengurangi volume sampah, juga untuk memperbaiki karakteristik sampah yang selanjutkan akan diolah di Tempat Pembuangan Akhir (TPA). Kegiatan TPS 3R diantaranya yaitu daur ulang dan penggunaan kembali sampah memiliki sejumlah keuntungan dalam proses pengolahan sampah secara keseluruhan, di antaranya yaitu mengurangi jumlah sampah yang harus dibuang sehingga diharapkan dapar mengurangi sumber daya yang dibutuhkan dalam mengelola sampah. Selain itu juga bisa dimanfaatkan sebagai tempat lapangan kerjaan baru melalui pengumpulan dan penjualan kembali bahan daur ulang sehingga terciptanya kegiatan ekonomi (Kasih et al., 2018).

Kondisi TPS 3R yang ada di DKI Jakarta saat ini memiliki kondisi yang belum maksimal dalam melaksanakan tugas 3R. Hal ini diketahui oleh peneliti dari salah satu organisasi yang bekerjasama dengan DLH Jakarta, yaitu InSWA atau Solid Waste Association. InSWA menyatakan bahwa masih banyak permasalahan yang terjadi pada TPS 3R, seperti masih belum memadainya fasilitasnya. Fasilitas yang dimaksud di sini adalah tidak adanya wadah pemilahan dan ruang penyimpanan serta menurunnya kualitas alat pencacah organik. Selain fasilitas yang belum memadai, terdapat TPS 3R yang masih mencemari jalan dan lingkungan sekitar.
Melihat kondisi TPS 3R seperti itu, maka perlu adanya perbaikan TPS yang mana membutuhkan dana perbaikan tidak sedikit. Oleh karena keterbatasan dana yang dimiliki oleh DLH, sehingga perlu adanya penentuan prioritas TPS $3 \mathrm{R}$ yang segera perlu diperbaiki. Hal ini membuat peneliti ingin membantu DLH dalam hal tersebut dengan cara membuat suatu sistem yang bisa membantu DLH dalam memutuskan TPS 3R mana yang perlu diprioritaskan untuk segera diperbaiki. Adapun metode yang digunakan untuk merancang sistem tersebut yaitu RAD (Rapid Application Development). Penggunaan RAD dirasa peneliti metode yang tepat untuk membangun sistem ini mengingat RAD memiliki keunggulan seperti memiliki tahapan development yang lebih singkat daripada metode konvensional dan juga bisa menghasilkan sistem sesuai dengan kebutuhan user (Aswati, 2016).

Untuk metode optimasi, yang berfungsi dalam hal memutuskan TPS 3R mana yang akan diprioritaskan untuk diberikan bantuan dana, peneliti menggunakan 2 metode optimasi yaitu fuzzy logic dan hill climbing. Fuzzy logic dimanfaatkan untuk menentukan prioritas kriteria keputusan dengan cara mengukur hasil penilaian seorang expert terhadap tingkat urgensi masing-masing kriteria. Hasil pengukuran tersebut kemudian dioperasikan untuk menguraikan keputusan alternatif. Adapun fuzzy logic juga bisa digunakan untuk menentukan sistem peramalan cuaca dan hasilnya yaitu peramalan bisa lebih baik dengan menggunakan variabel yang bervariasi dan dengan jumlah variabel yang banyak (Puspita dan Yulianti, 2016). Fuzzy logic juga digunakan oleh Sitohang dan Napitulu (2017) dalam menentukan penjualan rumah dengan hasil dapat diketahui beberapa bulan yang bisa mengalami kenaikan penjualan yang cukup dratis yaitu di bulan April, Juni dan Nopember. Selain itu fuzzy logic juga digunakan untuk mengelola masalah waste dan menghasilkan suatu sistem pengelolaan waste dengan penggunaan dana yang minimal (Kharat et al., 2018). Pengelolaan health-care waste juga pernah menggunakan fuzzy logic, sehingga didapatkan teknologi pengolahan health-care waste secara optimal (Liu et al., 2015). Ceron et al. (2017) memanfaatkan fuzzy logic untuk penilaian alternatif sustainable power generation melalui sistem optimasi yang dibangun dan sistem yang dihasilkan bisa dimanfaatkan untuk bentuk energi lain.

Metode optimasi selanjutnya yang digunakan oleh peneliti yaitu metode hill climbing. Metode ini digunakan oleh peneliti dalam melakukan perangkingan alternatif TPS 3R dengan menghitung jarak node terdekat. Metode ini juga sudah dilakukan oleh beberapa peneliti lainnya yaitu Dangkua et al. (2015) yang menggunakan hill climbing pada Sistem Informasi Geografis (SIG) untuk menentukan jarak terpendek. Hasil kombinasi metode hill climbing dengan SIG tersebut berupa aplikasi yang bisa 
mencari lintasan terpendek. Metode ini juga dimanfaatkan oleh Achnas et al. (2015) untuk penentuan harga jual rumah, dikombinasikan dengan metode fuzzy inference system Sugeno. Hasilnya adalah bisa memprediksi harga jual rumah dengan akurat. Sakamoto et al. (2018) menggunakan hill climbing untuk menentukan penempatan node pada perancangan system intelijen hybrid dan hasilnya adalah terpilih Wireless Mesh Networks (WMN) PSOHC DGA dibanding PSODGA.

Kedua metode optimasi ini digunakan dalam perancangan sistem yang menggunakan RAD, mengolah data-data berdasar kriteria-kriteria yang sudah ditentukan, yang mana kriteria tersebut didapatkan dari referensi-referensi jurnal yang sekiranya bisa digunakan dalam penelitian ini serta hasil obesrvasi dokumen yang berkaitan dengan pengelolaan TPS 3R. Sistem yang dihasilkan memberikan kontribusi kepada DLH untuk dapat memutuskan TPS 3R mana yang perlu diprioritaskan mendapatkan pendanaan perbaikan.

Adapun struktur penyajian artikel ini adalah: Bab 2 menyajikan metode penelitian yang berisi tahapan pengumpulan data dan pengembangan sistem. Bab 3 menjelaskan pengembangan sistem pendukung keputusan yang menggunakan fuzzy logic dan optimasi hill climbing. Bab 4 menjelaskan kesimpulan yang berisi hasil penelitian, kelebihan dan kelemahan fuzzy logic dan hill climbing, serta pengembangan penelitian lebih lanjut.

\section{METODE PENELITIAN}

Penelitian ini terbagi menjadi 4 tahapan, dimana setiap tahapan mengandung metode-metode penelitian yang digunakan yang terlihat pada Gambar 1.

\subsection{Analisis Awal}

Tahapan ini dilakukan dengan metode observasi untuk mengetahui permasalahan yang terjadi di objek penelitian sehingga bisa mengusulkan pemecahan masalah dengan apa yang dilakukan oleh peneliti.

\subsection{Pengumpulan Data}

Pada tahapan ini, metode yang dilakukan adalah observasi ke objek penelitian untuk mengetahui semua informasi yang berkenaan dengan tema penelitian yang diusulkan sebagai pemecahan masalah. Selain itu juga melakukan metode studi literatur yaitu dengan mencari, membaca dan menganalisis jurnal-jurnal, buku-buku referensi yang berkaitan dengan tema peneliti seta melakukan wawancara kepada narasumber di objek penelitian. Jurnal dikaji didasarkan pada domain riset yang sama yang mencakup metode, tool, kriteria/variabel yang digunakan.

\subsection{Pengembangan Sistem}

Dalam tahapan ini, metode yang digunakan untuk merancang sistem penelitian yaitu metode
RAD yang mengacu pada Kendall \& Kendall (2010). Tahapan tersebut terdiri atas perencanaan syarat, workshop design dan implementasi. Pada tahap perencanaan syarat terdapat analisis data dan analisis sistem berjalan maupun sistem usulan.

Tahap workshop design terdapat perancangan sistem dengan mengunakan metode optimasi fuzzy logic dan hill climbing yang mengacu pada Utama (2017) serta membuat use case diagram dan activity diagram hingga sequence diagram mengacu pada Rosa \& Shaladuddin (2011). Setelah itu membuat perancangan interface dengan membuat PHP template. Kriteria yang digunakan dalam metode optimasi ini terdiri atas luas lahan, fasilitas, jarak TPS ke pemukiman, kondisi jalan, dan kondisi estetika lingkungan. Sebagian besar kriteria tersebut tidak memberikan nilai kepastian, kejelasan dan ambiguitas, sehingga fuzzy logic sebagai salah satu teknik penalaran terbaik dalam menilai berbagai situasi dan permasalahan. Sedangkan hill climbing adalah metode optimasi yang merupakan sebuah pendekatan analisis untuk memperoleh nilai optimum dari alternatif yang ada khususnya menyelesaikan permasalahan pencarian jarak terdekat. Hill climbing memiliki keunggulan ketika nilai optimum ditemukan, maka proses akan berhenti tanpa membandingkan dengan nilai lain di sekitarnya. Proses ini lebih cepat untuk mendekati nilai optimumnya dan simple.

Tahap implementasi menggunakan MySql serta PHP mengacu pada Kustiyahningsih (2011) sebagai bahasa pemrograman serta menguji aplikasi dengan menggunakan Black Box Testing mengacu pada Rosa \& Shaladuddin (2011).

\subsection{Laporan dan Dokumentasi}

Tahapan pelaporan merupakan tahapan akhir dari serangkaian tahapan yang sebelumnya telah dilakukan. Dimana, pada tahapan ini hasil akhirnya adalah laporan hasil dari penelitian yang dilakukan.

\section{HASIL DAN PEMBAHASAN}

Pada tahap ini, peneliti melakukan hal-hal yang saling terkait dalam proses pembangunan sistem pendukung keputusan. Berikut ini merupakan penjelasan dari proses pembangunan sistem.

\subsection{Alur Proses Optimasi}

Gambar 2 menunjukkan alur proses optimasi dalam beberapa tahap. Tahapan pertama yaitu menentukan jumlah anggaran TPS 3R yang telah ditetapkan oleh pemerintah tiap tahunnya sebagai acuan penentuan kuota TPS 3R. Hal ini sangat berpengaruh terhadap pengelolaan TPS 3R 
disebabkan jumlah anggaran yang diberikan akan digunakan untuk keperluan pengelolaan TPS 3R kebijakan pemerintah terkait pemberian anggaran TPS 3R.

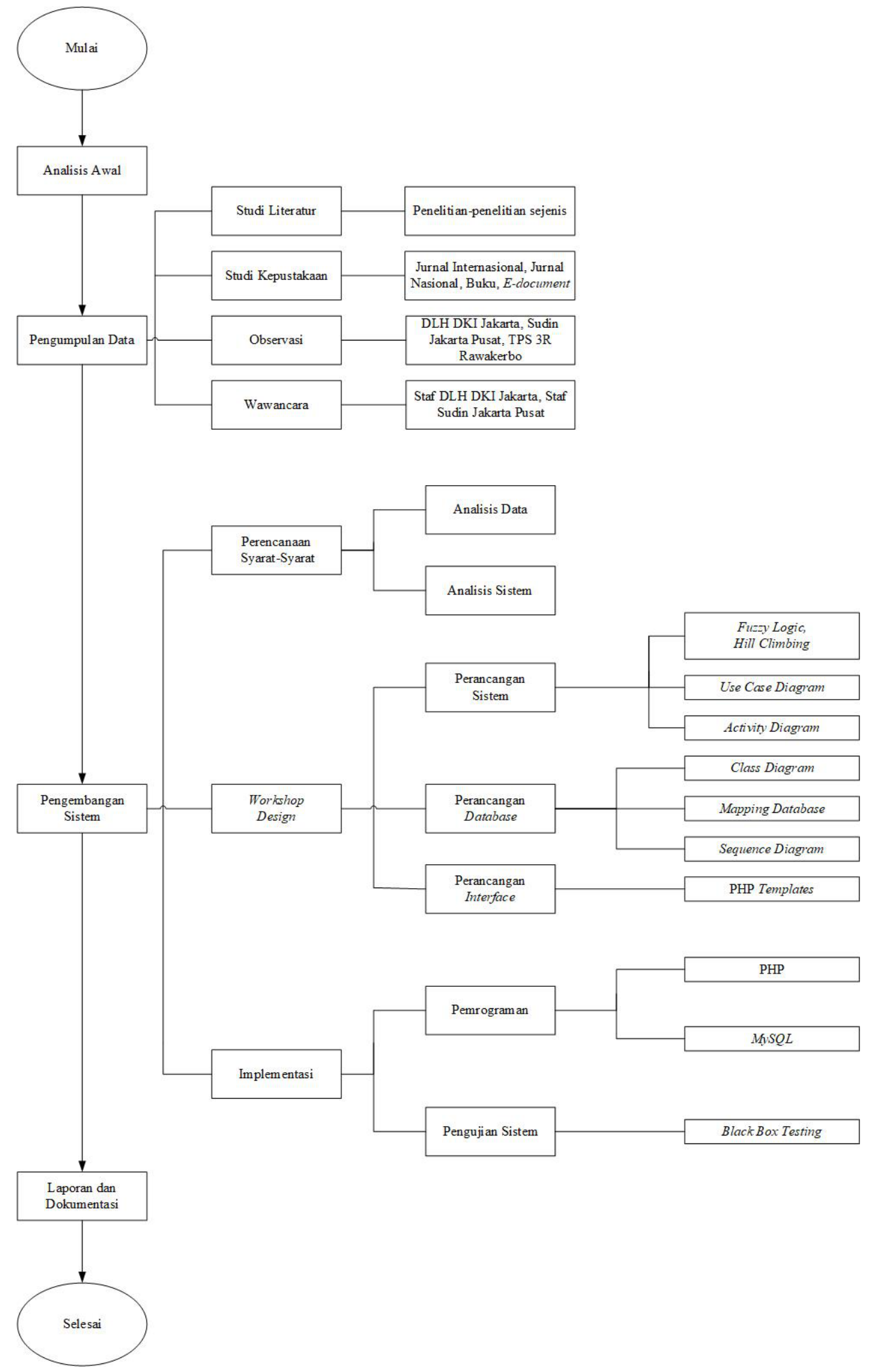

Gambar 1. Tahapan Penelitian

khususnya dalam bidang sarana dan prasana yang ada. Jumlah anggaran TPS 3R yang ditentukan sangat terbatas, sehingga berdasarkan anggaran tersebut dapat ditentukan berapa banyak TPS 3R yang mendapatkan anggaran. Hal tersebut berdasarkan
Tahapan kedua yaitu optimasi TPS 3R berdasarkan kriteria fasilitas dan nilai total penilaian TPS 3R tertinggi. Kriteria fasilitas diutamakan dalam proses optimasi dikarenakan TPS 3R mempunyai unsur penting di dalamnya, seperti fasilitas daur ulang 
sampah. Serta, total penilaian TPS 3R sebagai acuan dalam proses optimasi hill climbing. Sehingga saat melakukan proses optimasi, data TPS 3R yang memiliki fasilitas lengkap dan memiliki total penilaian tertinggi diprioritaskan menjadi TPS 3R yang diberikan anggaran.

Tahapan ketiga yaitu optimasi sisa TPS 3R berdasarkan jumlah sisa kuota TPS 3R yang tersedia. Jika pada tahapan kedua jumlah kuota TPS 3R sudah penuh dikarenakan jumlah data TPS 3R dengan kriteria fasilitas lengkap dan total penilaian tertinggi maka tidak perlu melakukan proses optimasi kembali, karena kuota TPS 3R sudah penuh. Namun, jika kuota TPS 3R masih tersedia maka melakukan proses optimasi kembali sesuai dengan metode hill climbing.

Setelah melewati ketiga tahapan tersebut didapatkan hasil optimasi TPS 3R yang menjadi prioritas mendapat anggaran pengelolaan TPS $3 \mathrm{R}$. Hasil optimasi tersebut selanjutnya akan divalidasi oleh Kaseksi sebagai penanggung jawab dalam penentuan anggaran TPS 3R dan memberikan hasil tersebut kepada Kasatpel, sehingga Kasatpel akan memberikan anggaran tersebut kepada TPS 3R yang telah terpilih dari hasil optimasi.

\subsection{Use Case Diagram}

Gambar 3 merupakan Use Case Diagram pada sistem dengan 7 proses Use Case yaitu: Login Pengguna, Mengelola data pengguna, entry data, perhitungan optimasi, validasi, laporan dan Logout Pengguna. Proses Login dilakukan agar setiap aktor dapat mengakses sistem sesuai dengan hak akses yang telah diberikan, lalu use case kedua yaitu entry data dilakukan untuk memasukkan data setiap TPS 3R kedalam database yang dilakukan oleh Staf Pengelola Kebersihan. Use case ketiga yaitu mengelola data pengguna ditentukan oleh admin.

Kemudian use case keempat yaitu proses perhitungan optimasi untuk mendapatkan nilai akhir yang melibatkan Kaseksi. Use case kelima yaitu validasi hasil optimasi untuk menyatakan hasil tersebut valid yang dilakukan oleh Kaseksi, sehingga proses pendanaan TPS 3R bisa dilakukan. Use case keenam yaitu rekapitulasi laporan adalah proses rekapan hasil optimasi yang telah valid sebagai track record proses pendanaan TPS 3R dari waktu ke waktu. Terakhir yaitu use case ketujuh, logout pengguna dimana proses melibatkan semua aktor untuk dapat keluar dari sistem.

\subsection{Fungsi Keanggotaan}

Fungsi Keanggotaan (Membership Functions) yang terlihat seperti pada Gambar 4, ditentukan berdasarkan penilaian kriteria-kriteria terkait dalam proses optimasi pengelolaan TPS 3R yang diberikan oleh para ahli di bidangnya (expert judgments). Hasil dari fungsi keanggotaan akan dilakukan perhitungan dengan pembobotan nilai dari skenario penilaian berdasarkan masing-masing kriteria dan mempengaruhi dalam hasil proses optimasi.

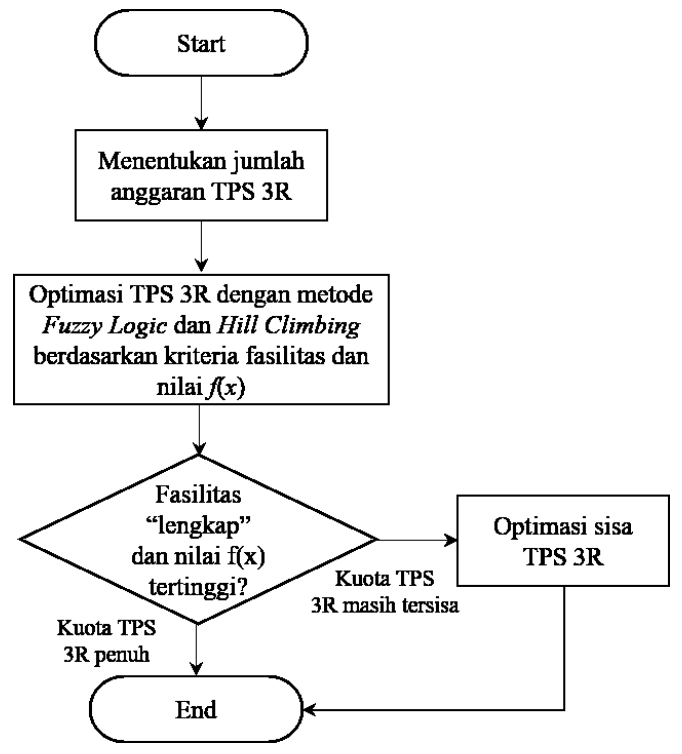

Gambar 2. Alur Proses Optimasi

Hasil fungsi keanggotaan dari expert judgements untuk kriteria-kriteria terkait optimasi pengelolaan TPS 3R yaitu, sebagai berikut:

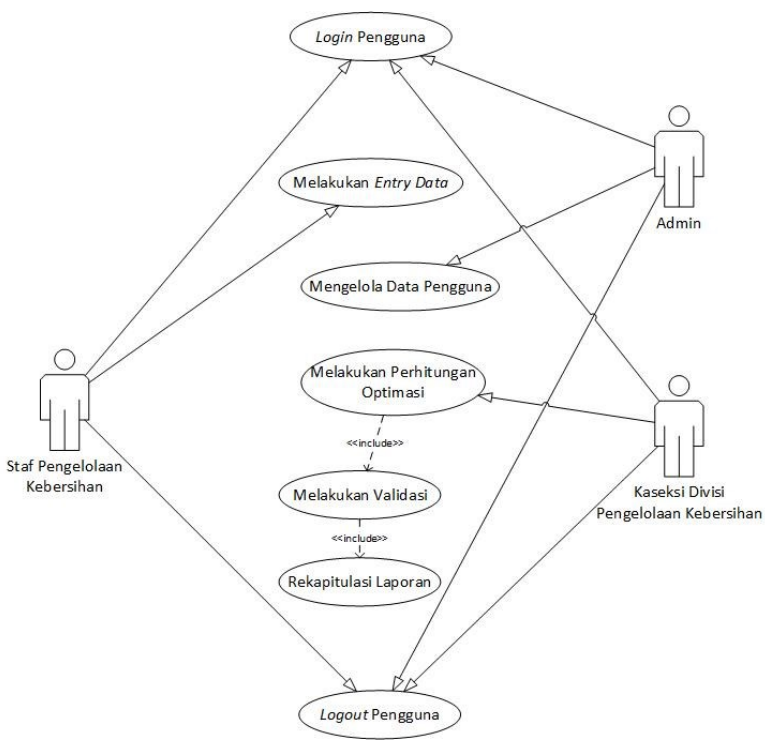

Gambar 3. Use Case Diagram

Diketahui:

a) Skala: Penting $=60-100$, Cukup Penting $=20-80$, Tidak Penting $=0-40$.

b) Crisp Value (CV) Input = nilai kepentingan kriteria yang diberikan oleh expert judgments.

c) Crisp Value (CV) Output = nilai kepentingan kriteria yang telah melalui proses fuzzifikasidefuzzifikasi. 


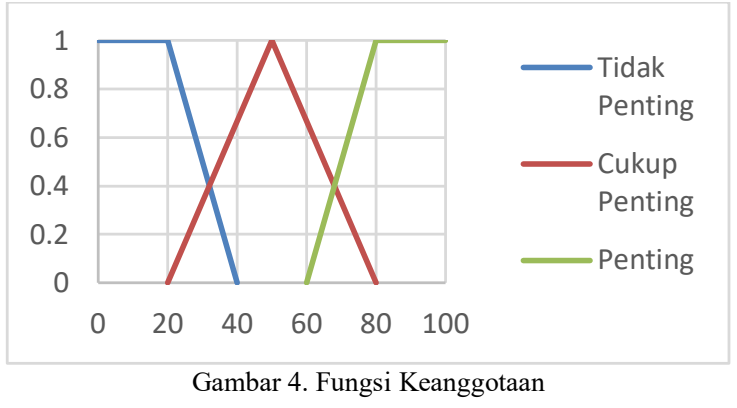

- Kriteria: Luas Lahan

CV Input Luas Lahan $=80 \rightarrow 1 \mathrm{P}$

CV Output Luas Lahan $=(1 \times 80)=80$

- Kriteria: Fasilitas TPS 3R

CV Input Fasilitas TPS 3R $=90 \rightarrow 1 \mathrm{P}$

CV Output Fasilitas TPS $3 R=(1 \times 90)=90$

- Kriteria: Jarak (TPS ke Pemukiman Warga)

CV Input Jarak $=70 \rightarrow 0,4 \mathrm{CP}$ dan 0,6P

CV Output Jarak $=(0,4 \times 60)+(0,6 \times 80)=72$

- Kriteria: Kondisi Jalan

CV Input Kondisi Jalan $=60 \rightarrow 0,7 \mathrm{CP}$ dan $0,3 \mathrm{P}$

CV Output Kondisi Jalan $=(0,7 \times 60)+(0,3 \times 80)=$ 66

- Kriteria: Kondisi Estetika Lingkungan

$\mathrm{CV}$ Input Kondisi Estetika Lingkungan $=55 \rightarrow 0,9 \mathrm{CP}$ dan $0,1 \mathrm{CP}$

CV Output Kondisi Estetika Lingkungan $=(0,9 \times$ $55)+(0,1 \times 80)=57,5(58) *$ pembulatan

Hasil Membership Functions:

- Crisp Value Output kriteria Luas Lahan $=80$

- Crisp Value Output kriteria Fasilitas TPS 3R=90

- Crisp Value Output kriteria Jarak (TPS menuju Pemukiman Warga) $=72$

- Crisp Value Output kriteria Kondisi Jalan = 66

- Crisp Value Output kriteria Kondisi Estetika Lingkungan $=58$

Dari hasil sebelumnya total Crisp Value Output dari semua kriteria $=366$, sehingga bisa didapat nilai bobot Crisp Value Output setiap kriteria yaitu:

$$
X n=\frac{\mathrm{Cn}}{\operatorname{SigmaC}}
$$

dengan $x_{n}$ adalah nilai bobot Crisp Output setiap kriteria dan $c_{n}$ merupakan nilai Crisp Output setiap kriteria. Sedangkan $\sum_{i=1}^{n} c_{n}$ adalah jumlah total keseluruhan nilai Crisp Output, sehingga didapatkan nilai:

$$
\begin{aligned}
& x_{1}=80 / 366=0,219 \\
& x_{2}=90 / 366=0,246 \\
& x_{3}=72 / 366=0,197 \\
& x_{4}=66 / 366=0,180 \\
& x_{5}=58 / 366=0,158
\end{aligned}
$$

dengan:

$$
\begin{aligned}
& x_{1}=\text { Luas Lahan } \\
& x_{2}=\text { Fasilitas TPS 3R } \\
& x_{3}=\text { Jarak (TPS ke Pemukiman Warga) } \\
& x_{4}=\text { Kondisi Jalan } \\
& x_{5}=\text { Kondisi Estetika Lingkungan }
\end{aligned}
$$

\begin{tabular}{|c|c|c|c|c|c|c|}
\hline $\begin{array}{c}\text { Kode } \\
\text { TPS 3R }\end{array}$ & $\begin{array}{c}\text { Luas } \\
\text { Lahan } \\
\left(\mathbf{m}^{2}\right)\end{array}$ & $\begin{array}{c}\text { Fasilitas } \\
\text { TPS 3R }\end{array}$ & $\begin{array}{c}\text { Jarak TPS - } \\
\text { Pemukiman } \\
\text { Warga } \\
\text { (m) }\end{array}$ & $\begin{array}{c}\text { Kondisi } \\
\text { Jalan }\end{array}$ & $\begin{array}{c}\text { Kondisi } \\
\text { Estetika } \\
\text { Lingkungan }\end{array}$ & $\begin{array}{c}\text { Total } \\
\text { Penilaian } \\
f(x)\end{array}$ \\
\hline T3R001 & 200 & Lengkap & 170 & $\begin{array}{l}\text { Cukup } \\
\text { Baik }\end{array}$ & Tidak Baik & \\
\hline T3R002 & 150 & $\begin{array}{c}\text { Tidak } \\
\text { Lengkap }\end{array}$ & 195 & $\begin{array}{l}\text { Tidak } \\
\text { Baik }\end{array}$ & Cukup Baik & \\
\hline T3R003 & 100 & $\begin{array}{l}\text { Cukup } \\
\text { Lengkap }\end{array}$ & 40 & Baik & Tidak Baik & \\
\hline T3R004 & 1000 & $\begin{array}{c}\text { Tidak } \\
\text { Lengkap }\end{array}$ & 70 & $\begin{array}{l}\text { Tidak } \\
\text { Baik }\end{array}$ & Tidak Baik & \\
\hline T3R005 & 730 & $\begin{array}{l}\text { Cukup } \\
\text { Lengkap }\end{array}$ & 250 & $\begin{array}{l}\text { Tidak } \\
\text { Baik }\end{array}$ & Baik & \\
\hline
\end{tabular}

\subsection{Skenario Penilaian}

Rumus perhitungan optimasi untuk pengelolaan TPS 3R berdasarkan kriteria-kriteria yang ada yaitu: $f(x)$

Contoh: Data TPS berdasarkan kriteria-kriteria yang ada dengan ketentuan-ketentuannya.

Tabel 1. Data Semua Kriteria

Berdasar data pada Tabel 1, didapatkan $R v$ (bobot nilai) dari setiap kriteria yang ada berdasarkan ketentuan-ketentuannya, sehingga dapat ditampilkan sebagai berikut.

Nilai Bobot Penilaian:

$$
\left[R_{v}=\frac{\text { ValueCur }}{\text { ValueMax }}\right]
$$

Tabel 2. Nilai Bobot Penilaian Semua Kriteria

\begin{tabular}{ccccccc}
\hline Kode & $\begin{array}{c}\text { Luas } \\
\text { Lahan } \\
\text { TPS 3R }\end{array}$ & $\begin{array}{c}\text { Fasilitas } \\
\text { TPS 3R }\end{array}$ & $\begin{array}{c}\text { Jarak TPS - } \\
\text { Pemukiman } \\
\text { Warga } \\
(\mathbf{m})\end{array}$ & $\begin{array}{c}\text { Kondisi } \\
\text { Jalan }\end{array}$ & $\begin{array}{c}\text { Kondisi } \\
\text { Estetika } \\
\text { Lingkungan }\end{array}$ & $\begin{array}{c}\text { Total } \\
\text { Penilaia } \\
\mathbf{n}\end{array}$ \\
\hline T3R001 & 0,2 & 1 & 0,5 & 0,5 & 0 & \\
T3R002 & 0,15 & 0 & 0,5 & 0 & 0,5 & \\
T3R003 & 0,1 & 0,5 & 0 & 1 & 0 & \\
T3R004 & 1 & 0 & 1 & 0 & 0 & \\
T3R005 & 0,73 & 0,5 & 0 & 0 & 1 & \\
\hline
\end{tabular}

Berdasarkan hasil perhitungan skenario penilaian secara keseluruhan didapatkan total penilaian dari setiap data berdasarkan kriteria-kriteria dan ketentuan-ketentuannya, sehingga dapat ditampilkan sebagai Tabel 3.

Dari hasil perhitungan pada Tabel 3, didapatkan bahwa T3R001 memiliki total penilaian tertinggi dengan nilai sebesar 0,478. Dengan demikian T3R001 diprioritaskan untuk diberi pendanaan, setelahnya diikuti dengan TPS 3R dengan nilai-nilai 
tertinggi setelahnya secara berurutan dan terusmenerus sampai semua kuota telah disediakan terpenuhi.

Tabel 3 Data Nilai Hasil Semua Kriteria

\begin{tabular}{ccccccc}
\hline Kode & $\begin{array}{c}\text { Luas } \\
\text { Lahan } \\
\left.\mathbf{( m}^{2}\right)\end{array}$ & $\begin{array}{c}\text { Fasilitas } \\
\text { TPS 3R }\end{array}$ & $\begin{array}{c}\text { Jarak TPS - } \\
\text { Pemukiman } \\
\text { Warga } \\
(\mathbf{m})\end{array}$ & $\begin{array}{c}\text { Kon } \\
\mathbf{d i s i} \\
\mathbf{J a l a} \\
\mathbf{n}\end{array}$ & $\begin{array}{c}\text { Kondisi } \\
\text { Estetika } \\
\text { Lingkungan }\end{array}$ & $\begin{array}{c}\text { Total } \\
\text { Penilaian } \\
\boldsymbol{f}(\boldsymbol{x})\end{array}$ \\
\hline T3R001 & 0,2 & 1 & 0,5 & 0,5 & 0 & 0,478 \\
T3R002 & 0,15 & 0 & 0,5 & 0 & 0,5 & 0,210 \\
T3R003 & 0,1 & 0,5 & 0 & 1 & 0 & 0,325 \\
T3R004 & 1 & 0 & 1 & 0 & 0 & 0,416 \\
T3R005 & 0,73 & 0,5 & 0 & 0 & 1 & 0,441 \\
\hline
\end{tabular}

\subsection{Hill Climbing}

Metode hill climbing dalam proses optimasi seperti yang terlihat pada Gambar 5, digunakan sebagai proses pemilihan alternatif terbaik atau dalam hal ini pemilihan TPS 3R yang menjadi prioritas utama berdasarkan hasil parameterisasi data TPS 3R dan penentuan jumlah anggaran. Dengan asumsi jumlah TPS 3R yang ada saat ini sudah sesuai dengan ketentuan, maka data TPS 3R yang dioptimasi menggunakan metode hill climbing berjumlah 522 TPS 3R

Data TPS 3R yang digunakan merupakan data dummy yang dibuat secara acak berdasarkan proses coding dengan berdasarkan ketentuan-ketentuan dari setiap kriteria dan menyesuaikan isi data semirip mungkin dengan data asli. Hal ini dilakukan karena data TPS 3R asli pada saat ini masih merupakan gambaran umum berdasarkan hasil survei dari setiap operator di masing-masing kotamadya, sehingga keabsahan data masih belum bisa dipastikan seiringnya perubahan data yang sering terjadi dan juga terdapat beberapa data yang sulit untuk didapatkan karena membutuhkan waktu yang cukup lama.

Hasil optimasi didapatkan berdasarkan nilai data TPS 3R yang terpilih secara acak, kemudian dibandingkan dengan nilai data TPS 3R sebelum dan sesudahnya dan nilai data TPS 3R tersebut dipilih sampai nilai data TPS $3 \mathrm{R}$ tersebut merupakan nilai tertinggi di antara nilai data TPS $3 \mathrm{R}$ sebelum dan sesudahnya, sehingga TPS-TPS 3R yang terpilih berdasarkan proses hill climbing merupakan alternatif terbaik dan yang dijadikan prioritas utama dalam proses pendanaan TPS 3R.

\section{KESIMPULAN}

Sistem ini dirancang dan dibuat untuk membantu pihak Dinas Lingkungan Hidup DKI Jakarta dalam proses pengambilan keputusan dalam hal pemilihan TPS 3R mana saja yang diprioritaskan untuk diberi pendanaan.

Kriteria yang digunakan dalam penelitian ini ditentukan berdasarkan hasil analisis data dan referensi terkait, sehingga terdapat 5 kriteria yang digunakan, yaitu Luas Lahan, Fasilitas TPS 3R, Jarak TPS ke Pemukiman, Kondisi Jalan, serta Kondisi
Estetika Lingkungan. Hal tersebut ditentukan dari hasil observasi langsung tempat penelitian, wawancara dengan narasumber, dan dokumentasi seperti peraturan perundangan pengelolaan sampah serta jurnal-jurnal terkait.

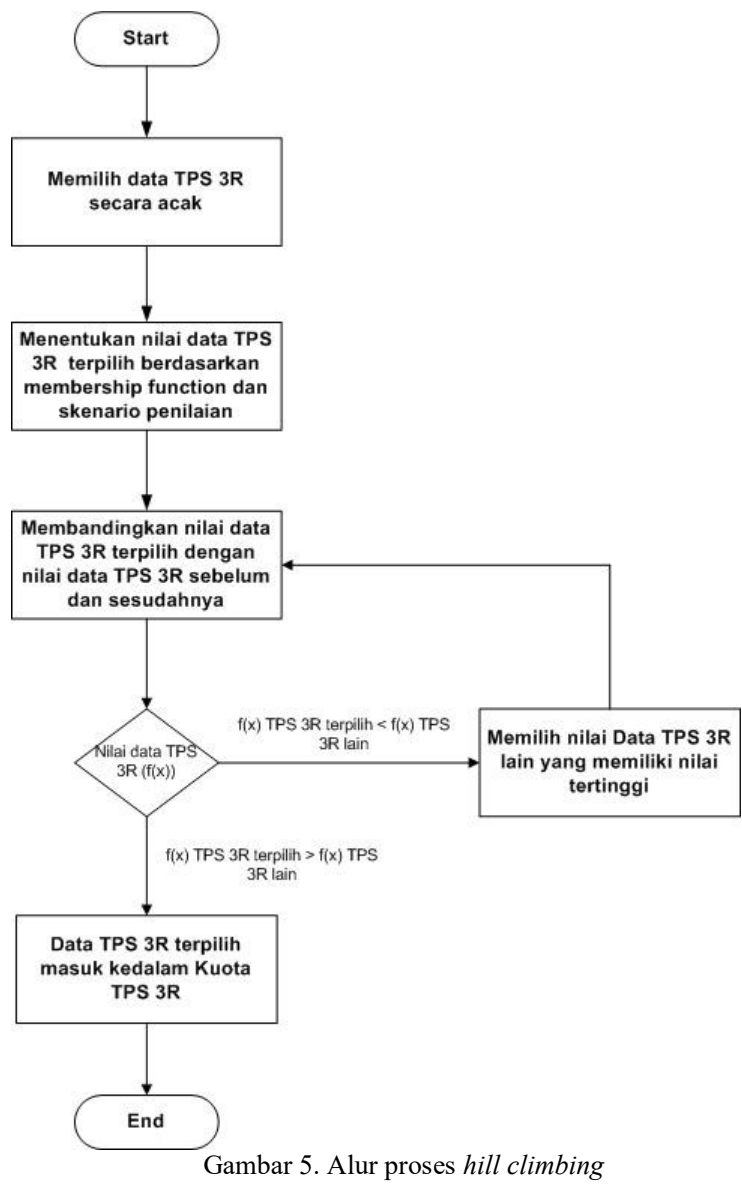

Metode fuzzy logic digunakan sebagai parameterisasi dari setiap kriteria yang telah ditetapkan berdasarkan nilai expert judgments untuk menentukan bobot nilai dari setiap TPS 3R yang menjadi prioritas utama dalam proses pemberian pendanaan, dimana kriteria fasilitas TPS 3R memiliki tingkat kepentingan tertinggi dari kriteria lainnya dengan nilai 0,246 yang dilakukan melalui proses membership function dan proses skenario penilaian. Sedangkan metode hill climbing digunakan sebagai metode optimasi pemilihan TPS 3R yang dijadikan prioritas utama dalam pemberian pendanaan secara acak, hal ini dilakukan dengan membandingkan setiap bobot nilai TPS 3R dengan TPS 3R lainnya dan mengambil TPS 3R dengan bobot nilai tertinggi sebagai prioritas utama dalam proses pemberian pendanaan.

Sistem yang dibangun ini memiliki beberapa fitur seperti menu data TPS 3R, menu optimasi untuk melakukan proses optimasi, validasi untuk memvalidasi laporan hasil optimasi, serta download untuk mengunduh laporan hasil optimasi yang telah divalidasi.

Kelebihan dan kelemahahan fuzzy logic dan hill climbing setelah diterapkan pada penelitian ini adalah 
mendapatkan hasil secara mudah dan cepat, karena hanya menganalisis 5 kriteria dan 67 data TPS, meskipun dengan metode hill climbing, nilai optimum tidak bisa langsung didapatkan, namun harus melewati level sedikit demi sedikit demi untuk mencapainya

Sistem pendukung keputusan ini dapat dikembangkan dengan menambahkan kriteria prosedur operasional dan sumber daya manusia, sehingga dapat memperkuat hasil pengambilan keputusan. Sedangkan proses translasi kriteria ke dalam bentuk kuantitas dapat menggunakan Analytical Hierarchy Process sebagai alternatif solusi dan dapat dibandingkan hasilnya. Beberapa metode pendekatan optimasi metahueristik dapat diterapkan seperti Simulated Annealing dan Water Flow Optimization. Dan tak bisa dipungkiri dari sisi pengguna, akses sistem dapat dikembangkan berbasis mobile.

\section{UCAPAN TERIMA KASIH}

Peneliti mengucapkan terima kasih yang tak hingga kepada pihak-pihak terkait penelitian seperti Divisi Pengelolaan Kebersihan DLH DKI Jakarta, InSWA dan TPA Bantar Gebang yang sudah bersedia meluangkan waktu, pikiran dan tenaga, sehingga terselesaikannya penelitian ini.

\section{DAFTAR PUSTAKA}

ACHNAS, A. H., CHOLISSODIN, I., MAHMUDY, W. F., 2015. Optimasi fuzzy inference system sugeno dengan algoritma hill climbing untuk penentuan harga jual rumah. Journal of Enviromental Engineering \& Suistainable Technology, 2(1), 31-36.

ASWATI, S., SIAGIAN, Y., 2016. Model Rapid Application Development Dalam Rancang Bangun Sistem Informasi Pemasaran Rumah (Studi Kasus: Perum Perumnas Cabang Medan). Seminar Nasional Sistem Informasi Indonesia. Surabaya: ITS.

CERON, A. M. R., KAFAROV, V., BAYONA, G.L., 2017. A Fuzzy Logic Decision Sustainable Alternatives for Power Generation in Non Interconnected Areas of Colombia-Cas of Study, 57, 421.

DANGKUA, E. V., GUNAWAN, V., ADI, K. 2015. Penerapan Metode Hill Climbing Pada Sistem Informasi Geografis Untuk Mencari Lintasan Terpendek. Jurnal Sistem Informasi Bisnis, 5(1), 19-25.

BPS Jakarta Data Penduduk DKI Jakarta, [online] Tersedia di: Data Penduduk DKI Jakarta $<$ https://jakarta.bps.go.id/statictable/2017/0 1/30/137/jumlah-penduduk-dan-rasio-jeniskelamin-menurut-kabupatenkota-diprovinsi-dki-jakarta-2015.html $>$ [Diakses 3 Mei 2020]
Dinas Lingkungan Hidup DKI Jakarta, 2017. Laporan Tempat Penampungan Sampah Sementara DKI Jakarta.

JAYANI, D.H., 2019. Jumlah Penduduk Dunia pada 2019 Capai 7,7 Milyar. [online] Tersedia di: $<$ https://databoks.katadata.co.id/datapublish /2019/09/10/jumlah-penduduk-dunia-pada2019-capai-77-miliar-jiwa> [Diakses $4 \mathrm{Mei}$ 2020]

KASIH, D., INDRAWAN, I., SETYOWATI, L., TANJUNG, M., SURYATI, I., 2018. Studi Perancangan dan Pemanfataan TPS 3R Untuk Sampah TPS (Tempat Pengolahan Sampah) Rumah Tangga. Jurnal Dampak, 15(1), 16-22.

KENDALL, K.E., dan KENDALL, J.E., 2010. Analisis dan Perancangan Sistem. Edisi 5. Diterjemahkan oleh: Thamir Abdul Hafedh. Jakarta: PT. Indeks.

KHARAT, M. G., MURTHY, S., KAMBLE, S. J., RAUT, R. D., KAMBLE, S. S., \& KHARAT, M. G., 2019. Fuzzy MultiCriteria Decision Analysis for Environmentally Conscious Solid Waste Treatment and Disposal Technology Selection. Technology in Society, 57, 20-29.

KUSTIYANINGSIH, Y., 2011. Pemrograman Basis Data Berbasis Web Menggunakan PHP \& MySQL. Yogyakarta: Graha Ilmu.

LIU, H. C., YOU, J. X., LU, C., dan CHEN, Y. Z., 2015. Evaluating Health-Care Waste Treatment Technologies Using A Hybrid Multi-Criteria Decision Making Mode. Renewable and Sustainable Energy Reviews, 41, 932-942.

NORKEN, I.N., HARMAYANI, K.D., dan KUNTAPARWANA, 2019. Analisis Resiko Pembangunan dan Pengelolaan TPS 3R (Reduce, Reuse, Recycle) di Kota Denpasar (Studi Kasus TPS 3R Desa Sanur KAUH). Jurnal Spektra, 7(2), 232-243.

PUSPITA, E. S., YULIANTI, L., 2016. Perancangan Sistem Peramalan Cuaca Berbasis Logika Fuzzy. Jurnal Media Infotama, 12(1), 1-10.

RAHAYU, Y.A., 2019. 2045, Indonesia Tak Lagi Jadi Negara dengan Penduduk Terbesar ke4 di Dunia. [online] Tersedia di: $<$ https://www.merdeka.com/uang/2045indonesia-tak-lagi-jadi-negara-denganpenduduk-terbesar-ke-4-di-dunia.html $>$ [Diakses 4 Mei 2020]

ROSA, A.S. dan SHALADUDDIN, M., 2011. Modul Pembelajaran Rekayasa Perangkat Lunak (Terstruktur dan Berorientasi Objek). Bandung: Modula.

SAKAMOTO, S., BAROLLI, L., BAROLLI, A., TAKIZAWA, M., 2018. Design and Implementation of a Hybrid Intelligent 
System Based on Particle Swarm Optimization, Hill Climbing and Distributed Genetic Algorithm for Node Placement Problem in WMNs: A Comparison Study.

SITOHANG, S. dan NAPITULU, R. D., 2017. Fuzzy Logic Untuk Menentukan Penjualan Rumah dengan Metode Mamdani (Studi Kasus: PT Gracia Herald). Jurnal ISD, 2(2), 91-101.

UTAMA, D. N., 2017. Sistem Penunjang Keputusan: Filosofi, Teori dan Implementasi. Yogyakarta: Garudhawaca. 
Halaman ini sengaja dikosongkan 